\section{International Activity of the Council on Cooperation in the Field of Public Health of NIS Countries for Emergencies and Acts of Terrorism Prevention and Relief}

Prof. V.B. Korbut

All-Russian Centre for Disaster Medicine ("Zaschita"), Moscow, Russia

The Council on Cooperation in the field of public health of NIS countries is a profile working body of the NIS Executive Committee. During its regular sessions (twice each year), the council considers the most urgent topics in cooperative arrangements for prevention and relief during emergencies and acts of terrorism.

Since 1994, the council has included the coordinating group for disaster medicine problems of NIS countries. The chairman is Deputy Minister of Public Health of the Russian Federation. During each session, the council considers 4 to 5 topics on disaster medicine. The Council ratified 11 interstate documents on disaster medicine (training programs, vocabulary of terms, textbook, methodical documents).

In 1996, during an international conference, Command-Staff Exercises (CSE) relative to disaster medicine problems following earthquakes were held. International CSE "Management of Emergency Medical Relief in a Military Conflict" is to be held in 2003 in Dushanbe, Tajikistan. The Council ratified an Activity Coordination Program for emergency prevention and health relief on the territories of NIS countries for 2001-2003, and the Plan of Cooperation and Mutual Assistance of Disaster Medicine Services of the NIS countries in emergencies.

These documents envision the elaboration of a coordination doctrine of medical assistance for the injured during an emergency, including: (1) training of managerial bodies, institutions, and units for work during emergency conditions; (2) determination of the connection and the emergency notification order; (3) coordination of the force requirements and the Disaster Medicine Service resources needed for emergency health relief; (4) production of a sufficient supply of medical equipment; (5) information exchange, including the facts regarding the nature of the emergency, and the expected emergency health relief measures that will be required; (6) provision of the required manpower and supplies; (7) provision of medical staff, victims, and the population defense; and (8) organization and implementation of measures for maintaining the sanitaryepidemiological well-being.

Keywords: assistance, mutual; cooperation; coordination; Council on Cooperation; disaster medicine; doctrine; documents; emergency conditions; information; NIS; planning; relief; resources; training

Prehosp Disast Med 2003:18:s(1)s26.

E-mail: rcdm.org@ru.net

\section{Thursday, 04 September Terrorist Threat}

\author{
Hospital Preparedness for Mass Casualties \\ LTC (Ret.) Mauricio Lynn, MD \\ Ryder Trauma Center, Jackson Memorial Hospital, University of \\ Miami School of Medicine, Miami, Florida, USA
}

Mass Casualty Incidents (MCIs) occur as an "act of God", accidents, or acts of terrorism. These events have claimed countless lives worldwide over the past 20 years. On 11 September, 2001, the recognition that those living in the United States of America were at risk in their own land due to terrorism became hauntingly real. U.S. intelligence communities agree that the weapon most likely to be used by terrorist to inflict significant injuries within the Untied States homeland is a conventional bomb. Any significant and effective preparation and response to a MCI must be based upon a firm understanding of the predicted "natural history" of the anticipated event. A nuclear weapon would create a large number of victims over a protracted timeframe of weeks, months, and years. The initial events of a biological event will be delayed and insidious, but will evolve rapidly and mimic a conventional event. Explosions and chemical contaminations produce an immediate and immense number of victims. The Tokyo subway Sarin gas attack in 1995, produced 5,500 contaminated victims in an overwhelmingly short period of time that required medical attention at local hospitals. The car bomb explosion in Nairobi, near the American Embassy, killed almost 300 people. Thousands required immediate medical care at local hospitals. Once an effective, consistent, and proven response and management process to a sudden $\mathrm{MCI}$ is established, this medical and logistical infrastructure could facilitate its adaptation to events that are insidious by nature.

Keywords: adaptation; events; hospitals; injuries; mass casualties; mechanisms; preparedness; responses; terrorism Prehosp Disast Med 2003;18(s1)s26.

Email:MLynn@med.miami.

\section{Mass Casualty Terrorist Bombings: Implications for Emergency Department Response Jeffrey Arnold, MD, FACEP, FAAEM \\ Department of Emergency Medicine, Baystate Medical Center, Tufts University School of Medicine, Springfield, Massachusetts,USA}

Despite recent concerns about weapons of mass destruction, explosions are by far the most common cause of disasters associated with terrorism. Of 93 reported terrorist acts producing 30 or more casualties in the world from 1991 to $2000,82(88 \%)$ involved explosions. These attacks not only resulted in significant death and destruction but also challenged emergency medical systems in 27 countries. ${ }^{1}$ The largest of these bombings were catastrophic medical disasters, generating hundreds to thousands of casualties and acutely overwhelming local prehospital and emergency department resources.

Emergency departments (EDs) play a pivotal role in the immediate medical response to terrorism-related bombing 
emergencies. EDs not only perform triage, provide treatment, and determine the disposition of immediately surviving injured victims, they also provide prehospital medical control, manage medical resources, solve logistical problems, and help calm a terrified public. All of these functions must be based on a clear understanding of the mechanisms, types, frequency, severity, and time course of injuries in terrorist bombings and a familiarity with the many lessons learned from past responses to terrorist bombing disasters.

This presentation reviews the epidemiology of masscasualty terrorist bombings and discusses the implications for ED response. Although it is prudent to "expect the unexpected," a rational approach to disaster management incorporates what is already known into the basis for planning and preparedness. As long as terrorists continue to use explosions to achieve their goals, terrorist bombings must remain a focus of medical disaster preparedness.

References

1. Terror Attack Database. International Policy Institute for Counter-Terrorism Web Site. Available at:

http://www.ict.org.il/. Accessed August 1, 2003.

Keywords: bombing; disaster; emergency department (ED); explosion; mass casualty; terrorism

Prehosp Disast Med 2003:18:s(1)s27.

E-mail: Arnoldmdes@cs.com

\section{Terrorism, et al.}

Marvin L. Birnbaum, $M D, P h D$

Professor of Medicine and Physiology, University of Wisconsin-

Madison, USA; Editor-in-Chief, Prehospital and Disaster

Medicine, World Association for Disaster and Emergency

Medicine

A new medical/public health definition of "terrorism" has been proposed:

The intentional use of violence-real or threatened- against one or more non-combatants and/or those services essential for or protective of their health, resulting in adverse health effects in those immediately affected and their community, ranging from a loss of well-being or security to injury, illness, or death.

Given this definition, it should be clear that, medically, acts of terrorism are conducted to induce fear and insecurity in the target population. Thus, the impact of an act of terrorism not only produces damage in the form of death and physical injury, but also results in profound psychosocial effects upon the directly affected population and also on the world community in the form of terror, fear, and post-traumatic stress disorders. The acts of 11 September 2001 (9/11), although medically manageable at the time, are now producing a medical disaster, as the ongoing psychosocial effects threaten to overwhelm the medical community and require substantial outside assistance.

Following $9 / 11$, the responses to terrorism at an international level have resulted in the provision of vast amounts of resources supposedly directed toward the prevention of such events and toward the enhancement of our ability to respond if and when they do occur. In the United States, huge sums of money have been granted to the states to enhance their level of preparedness for the next major event. Unfortunately, little vision and guidance have accompanied these resources, and the funds are being spent in an uncoordinated fashion. There is little evidence that expending such funds have created enhanced preparedness.

Another problematic response to $9 / 11$ has been the government's periodic announcements that the threat level of terrorism has been raised or lowered, without providing any more specific information. This creates additional fear, which is unattached and psychologically disturbing. Such activities feed the underlying objectives of creating terror, fear, and insecurity. Over time, they also can induce complacency. Such activities are deleterious rather than helpful.

A positive aspect of this heightened awareness of terrorism is that in the past few years, we have been able to make more progress toward preparedness for all hazards than we have been able to achieve in disaster preparedness during the last half century! We have an unprecedented opportunity to enhance our preparedness and ability to respond to any hazard. After all, is the risk that a terrorist event will produce a massive number of casualties greater than that of any other kind of catastrophic event?

Keywords: 9/11; 11 September 2001; attacks; definition; fear; haz-

ards; impact; insecurity; preparedness; resources; terror; terrorism Prehosp Disast Med 2003;18:s(1)s27.

E-mail: mlb@medicine.wisc.edu

\section{Plenary Sessions}

\section{Civilian-Military Cooperation and the Use of Military Assets in Disaster and Humanitarian Relief Operations}

Knut Ole Sundnes, $M D$

Head, Office for War Surgery and Emergency Medicine, Norwegian Defence Forces; President, World Association for Disaster and Emergency Medicine

As a relatively new term, civilian-military cooperation (CIMIC) is but a new name for an aspect of the larger scope of civilian-military interrelationships. Such a civilian-military relationship covers a variety of scenarios, ranging from exclusively humanitarian assistance, or provision of peace-support operations, to war and occupation of a country. It's relatively recent in history (within the past 150 years) that these interrelationships have been "regulated" by conventions and international legislation. They now are governed by an increasing number of doctrines: Some are legally binding international conventions, others serve as rules of engagement for military alliances, and others represent ethically binding conventions and declarations.

The historical rationale for maintaining military forces has been for protection (defense) or for aggression (annexation). These may be fully professional armies with paid soldiers or drafted personnel doing compulsory military service. For both types, the core of the military is the combatants. But, except in peace-support operations, the same elements that provide support for the combatants are the assets most often called upon to provide humanitarian assistance, e.g., engineering support, logistics, and medical support. In fact, today the military is the only complete system that has the capacity to manage all manageable disasters. However, history serves as a serious obstacle for the 